\section{Mr. W. Wessels}

Department of Practical

Theology, Faculty of Theology

and Religion, University of

Pretoria.

(orcid.org/0000-0002-3709-6363)

uwessels@pm.me

DOI: http://dx.doi.

org/10.18820/23099089/

actat.Sup29.10

ISSN: 1015-8758 (Print)

ISSN: 2309-9089 (Online)

Acta Theologica 2020

Supp 29:176-194

Date received:

4 June 2020

Date accepted:

30 June 2020

Date published:

30 November 2020

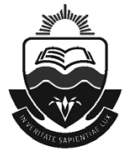

Published by the UFS http://journals.ufs.ac.za/index.php/at (c) Creative Commons With Attribution (CC-BY)

OPEN ACCESS

\section{ON JUSTICE AND BEAUTY IN RECENT SOUTH AFRICAN HOMILETICS: A POST-COLONIAL REFLECTION ${ }^{1}$}

\begin{abstract}
In recent South African homiletics, two major themes have experienced overwhelming attention: prophetic preaching and aesthetics. Prophetic preaching endeavours to seek social, political, and economic justice. Aesthetic homiletics considers beauty for preaching. In this article, I grapple with the convergences and divergences of justice and beauty in South African homiletics. With the hope of opening new avenues for future endeavours, I also reflect on both prophetic preaching and aesthetic homiletics from a post-colonial perspective.
\end{abstract}

\section{INTRODUCTION}

Since the dawn of constitutional democracy in South Africa, South African homiletic contributions have intersected around two main focal images: prophetic preaching and aesthetics. Prophetic preaching is the earlier development and is centred around the insights of Black Theology of Liberation for preaching within the new context of democracy. Aesthetic homiletics developed roughly a decade later. Between and among thoughts on prophetic

1 This article is based on the unpublished PhD thesis: Wessels (2020). Postcolonial homilectics? A practical theological engagement with postcolonial thought. 
preaching and aesthetics, there has been a constant discourse of convergence and divergence. In this article, I trace the major themes of prophetic preaching as a search for social justice in democratic South Africa. I also contemplate the convergences and divergences of aesthetic homiletics with prophetic preaching to trace the interaction of beauty and justice in the South African homiletic landscape. Within these contemplations, I reflect from a post-colonial perspective with the view that post-colonial insights search for newness entering the world.

\section{PROPHETIC PREACHING}

In 1995, Pieterse published a research project, Desmond Tutu's message: A qualitative analysis, which focuses on Desmond Tutu's anti-apartheid sermons. Three important points are made. First, Pieterse (1995:96) called Tutu's preaching steeped in Black Theology of Liberation, "critical prophetic preaching". Secondly, Pieterse, Scheepers \& Wester (1995:55) proposed that these prophetic sermons were underscored by a "vision for the South African society, which is ... based on [Tutu's] Christian interpretation of the reign of God". Thirdly, Tutu's sermons rose above the politics of apartheid (Pieterse et al. 1995:48).

At the intersection of these three points, Pieterse (1995:97) made the following proposal for a model for preaching in democratic South Africa:

[L]iberation theology and prophetic preaching should guide the churches' contribution to the struggle for LIBERATION FROM POVERTY [sic] through reconstruction and development.

This sentence represents the watershed moment where Black Theology of Liberation was coined prophetic preaching: "[P]reaching which is keenly aware and takes serious [sic] the ethical-political-societal dimensions of preaching" (Laubscher \& Wessels 2016:178). Previously, Black Theology of Liberation was univocally practised from the perspective of Black oppression as "a relevant gospel to the Black community" (Boesak 1984:29). In the apartheid context, Black Theology of Liberation empowered Black people, claiming that God is among them in their struggle for freedom (see Mofokeng 1987:4, 15).

However, Pieterse's proposal led to a change, and newness entered the homiletic landscape. Pieterse grappled earnestly with the global neoliberal economy of which South Africa became part in 1994. Moreover, this endeavour envisioned an intersection between the insights of Black Theology of Liberation, the potential of preaching, and the parameters of neoliberal capitalism. This was essentially a novum and notable 
contribution. Furthermore, Pieterse's study was the first instance in South African homiletic thought where Black Theology of Liberation is considered in a positive light. Previously, Black Theology of Liberation was either wholly ignored (see Vorster 1992:451-463) or vehemently opposed (see Smith 1987:106). Internationally, on the other hand, there is a tradition of prophetic homiletics that has contemplated the ethical, political, and societal aspects of preaching (see Brueggemann 1978; Harris 1995).

Something exciting took place in the historical development of prophetic preaching since Pieterse's coinage thereof. At first, Pieterse singlehandedly contemplated prophetic preaching as sociopolitical preaching steeped in Black Theology of Liberation within the democratic context. I want to propose that Pieterse was the only homiletic theologian who considered prophetic preaching up to the late 2000s. In this time, Pieterse's idea of prophetic preaching developed through at least three discernible stages: the state of poverty within economic globalisation; rich church, poor church, and speaking out against corruption.

In Preaching in a context of poverty, Pieterse (2001) outlines a positive description of the global economic system and liberal democracy within the new South Africa. The hope for a better future in South Africa revolved around job creation in the public and private sectors as endeavour to curb the problem of poverty (Pieterse 2001:64-68). It should be noted that Pieterse also opined that informal job creations through faith community networks play a role worth mentioning (Pieterse 2001:69). When it comes to prophetic preaching, Pieterse (2001:92) underscored the homiletic and hermeneutic process with the caveat that the "preacher must be existentially familiar with the local context of poverty". In my opinion, Pieterse set the stage for prophetic preaching as hyper-contextual preaching. With this, I mean that prophetic preaching becomes contextual to the point where the context is so all-encompassing and overwhelming that an imagination beyond the context of poverty becomes impossible for prophetic preaching.

It is from this point of departure that Pieterse moved to the work of the rich church and the poor church. To be clear, Pieterse used the terms "church for the poor" and "church of the poor" (Pieterse 2001:112; 2002:559, italics in original). In an attempt to constitute relationality between preaching, poverty, and this dualistic church, Pieterse (2001:121) outlined "a theory which combines prophetic preaching with diaconal community development". This implies a "missionary diaconate", where the rich church aids the poor church, in collaboration with governmental and non-governmental organisations, in the endeavour of poverty relief (Pieterse 2001:118-120; 2002:559). Although Pieterse called for equal 
cooperation among these churches, the duality unintendedly invalidates egalitarian collaboration. Pieterse's prophetic preaching inevitably lost all possibilities of imagination beyond the contextual limits and became a hyper-contextual ecclesiology of development and poverty relief with sermons underscoring this agenda.

Already in Preaching in a context of poverty, Pieterse (2001:90) opined that prophetic preaching will expose all forms of power abuse which "weaken and jeopardise the position of the poor". When Pieterse wrote these words, he made no mention of any corrupt dealings within the government and spoke mostly in a positive tone about the administration of South Africa (Pieterse 2001:60-69). However, since the presidency of Jacob Zuma, a myriad of homiletic theologians started contemplating prophetic preaching as preaching that exposes corruption (see De Wet \& Kruger 2013; Pieterse 2013; Tubbs Tisdale \& De Wet 2014; Cilliers 2015; Kruger \& Pieterse 2016; Wessels 2017; Wepener \& Pieterse 2018). I opine that the convergence of understanding that prophetic preaching exposes power abuse with the contextual realities of corruption in democratic South Africa sparked this overwhelming contemplation on prophetic preaching. To be clear, homiletic theologians are not in exact agreement as to what prophetic preaching entails. Tubbs Tisdale and De Wet (2014:4-8) determined at least four visions for prophetic preaching in South Africa. There are even more at present, but the point remains, within the context of political corruption, prophetic preaching as exposing corruption becomes the perceived be-all and end-all of homiletic thought.

\section{REFLECTING ON PROPHETIC PREACHING'S PURSUIT OF ECONOMIC JUSTICE}

As mentioned earlier, the endeavour of Pieterse to integrate Black Theology of Liberation and the democratic context through prophetic preaching is remarkable. At the same time, when prophetic preaching becomes the trend of homiletic thought during corruption, thorough reflection becomes necessary. Moreover, later movements in Black Theology of Liberation and new contemplation on post-colonial theory paint a complex picture with regard to the relationship between liberation and economic globalisation. Once more, prophetic preaching as an endeavour to pursue economic justice must be scrutinised.

In his book on literature, Decolonising the mind, Wa Thiong'o (1986:108) concludes that his endeavour is "a call for the rediscovery of the real language of humankind: the language of struggle". In later contemplation 
on the insights language of struggle brings to the table, Wa Thiong'o (1993:26) makes the following comment:

But [the literature of struggle] did point out the possibility of moving the centre from its location in Europe towards a pluralism of centres; themselves being equally legitimate locations of the human imagination.

The point being made by Wa Thiong'o is the necessity for speaking of (and perceiving) the world from the location of struggle. Thus, there is a movement from a fixed and normative centre of location (the Western centre) towards locations of culture of struggle. However, this movement does not propose a new fixed centre, but rather the possibility of pluralism of locations of culture whence the world can be perceived (see also Mignolo 2000:721; Drichel 2008:605).

Although Black Theology of Liberation is a theology of struggle and rightly so a post-colonial theology, its hermeneutical centre must be critiqued. For Black Theology of Liberation during apartheid, the hermeneutic centre was the location of culture of Black people as oppressed and colonised in South Africa (see Boesak 1984:29; Maimela 1987:44; Mofokeng 1987:10; 1987b:24; Mosala 1987:32-34; Motlhabi 1987:4-5; Ramose 1988:21). In West's (2016:353-354) opinion, the marginalised, poor, and oppressed are still the interlocutors for the hermeneutics of Black Theology of Liberation in democratic South Africa. I opine that Black Theology of Liberation's insight for moving the epistemological centre to the margins is essential and profound. This is a hermeneutical move Pieterse (1995:79; 2001:92) also made, following suit.

However, from a post-colonial perspective, this movement of the hermeneutical centre to a new fixed and normative centre is problematic for three reasons. First, it underscores Western epistemology, which works with the concept of one normative centre whence thinking can take place, excluding all other centres. Secondly, it undermines the existential limits of one's location of culture, proposing that anyone could ipso facto imagine and experience the location of culture of the other. Thirdly, it becomes blind to changes in interlocutors.

With regard to the first reason, a new fixed centre excludes other epistemological possibilities, which undermines the struggle for human liberation, privileging some locations of culture over others. Secondly, the possibility of misrepresentation enters the endeavour (see Bhabha 1994:217; Drichel 2008:589). Thirdly, as Vellem (2012:4) proposes, Black Theology of Liberation's real interlocutor in democratic South Africa is "a black middle[-]class person rather than the poor non-person". 
Returning to prophetic preaching, all three of these critical points are also reasonable critique for prophetic preaching. If prophetic preaching should be from the perspective of the poor, what is the relationship with other locations of culture? Secondly, is it possible, for example, for a middle-class religious leader to understand the existential experience of poverty? Are the poor in reality the interlocutors of prophetic preaching?

I opine that the interlocutor of prophetic preaching in a context of corruption is a middle-class White person rather than the poor nonperson. This change of interlocutor influences all three points raised earlier. But first, let me interrogate the interlocutor of prophetic preaching in more detail.

The first and most obvious indication of a change in the interlocutor is the timeframe - at the height of governmental corruption - in which prophetic preaching became the normative conversation among South African homiletic theologians. At the same time, the goal of prophetic preaching becomes that of exposing corruption:

Every preacher should discerned [sic] the content of our prophetic preaching in contemporary South Africa in the specific context of the congregation. General issues that can be addressed are corruption by officials administering state funds, maladministration of state funds and unskilled people in crucial positions in the private sector who cannot do the job, but are there because they are ANC cadres due to the policies by the government to redeploy people to other positions after they are found guilty of corruption or maladministration in a previous government position (Pieterse 2013:5).

In our view, the essence of prophetic preaching is that it proclaims the biblical message critically in a society that tends to deviate from its God-given form and destiny, in the process equipping Christians to radiate the light of the kingdom of heaven and its righteousness revealingly and energisingly with a view to refocusing the world on its destiny in a restored relationship with God (De Wet \& Kruger 2013:7).

But the main issue is still how Christians and Christian leaders can start to act against corruptive practices. It is clear that it will be irresponsible if churches remain silent (Kruger \& Pieterse 2016:90).

As noted earlier, one of Boesak's leitmotivs in his theology is that evil is real. $\mathrm{He}$ is of the opinion that the evil in the world should be named. Naming evil is the moment when the church becomes aware of the calling of God to participate in the mission of God to abolish all evils (Wessels 2017:198). 
The point I want to propose is this: Prophetic preaching only becomes the focal point for homiletic thought once the White middle-class person's livelihood is in jeopardy, due to government corruption. From this insight, the poor become merely the proxy interlocutor to petition for the rights and privileges of the White middle class. Stated differently, prophetic preaching within homiletic thought only uses "an imaginary agent interlocutor in some imaginary South African township" (Maluleke \& Nadar 2004:7) to advocate on behalf of the White middle class.

The acute perceiver of the situation would realise that the positionality of the poor in the current South African context, whether corruption is prevalent or not, is a non-person without agency or value. To state it in the words of Vellem (2018:10,12, italics in original):

I wonder if there is anything moral or ethical about capitalism or neoliberal capitalism ... The restoration of the authority of the people means the restoration of identity-sustaining narratives and their compatible logically coherent ethical arguments with the feasibility of the planning of courses of action. It means that the victims of colonization and apartheid become in charge of the terms of economics, not just the critique of the content of economic justice.

Thus, in prophetic preaching's pursuit of economic justice, the epistemological underscoring of the status quo as neoliberal capitalism as well as the actual interlocutor of prophetic preaching become a stumbling block for contemplation on justice. Under these conditions, adequate representation of the poor, the struggle for justice, and the poor as genuine interlocutors for prophetic preaching become questionable.

\section{AESTHETIC HOMILETICS}

Although I am convinced of the overwhelming presence of prophetic preaching in recent homiletic thought, another important focal image is that of aesthetic homiletics. Cilliers has by far the largest body of work on aesthetics. I will also contemplate Nell's and Vos' contributions.

\subsection{Convergences of aesthetic homiletics and prophetic preaching}

Aesthetic homiletics and prophetic preaching converge at the intersection where aesthetic homiletics attempts to re-envision prophetic preaching.

Cilliers (2015:373) questions whether the term prophetic preaching is helpful and believes that how prophetic preaching is understood 
within South African homiletics reveals "a theological unsophisticated" comprehension of preaching. ${ }^{2}$ Cilliers (2015:374) goes on to show that prophetic preaching becomes merely the blending of political and eschatological language on the pulpit anywhere on the spectrum of political alliance. Thus, some preachers can understand their prophetic task as a challenge to the political status quo (see Cilliers 2019:99-145), others as the preservation of the status quo (see Cilliers 2006), and still others as complete silence on the status quo (see Cilliers 2019:42-64).

As an alternative, Cilliers (2015:378-379) reinterprets Tutu's preaching as anticipation for God's eschatological-political future through imagination inherently relativising the status quo of the present. Thus, the present becomes penultimate and God's future, ultimate. Cilliers identifies the following themes in Tutu's sermons: an inclusive rhetoric which transgresses the boundaries of the status quo (see Cilliers 2016:30-31); an invitation into the eschatological-political future of God already breaking through in the present; humour which underscores the penultimate nature of the present, and God-images that surprise and do not adhere to a preconceived motif for God (Cilliers 2016:31).

The alternative which Nell (2009:571) places on the table in conversation with prophetic preaching is "a theodramatic paradigm". What the theodrama sets forth is the insight that not only right understanding and preaching is essential (which Nell believes prophetic preaching indeed possesses), but also right living through acting out the drama of God (Nell 2009:572). In this line of thought, the pastor becomes the director of the church as a prophetic community "by acting as a community of love and justice" (Nell 2009:572). From here, Nell turns to the Confession of Belhar to help make meaning for the theodrama within the context. He proposes three acts: the taking of hands, the embrace of each other, and giving back the bicycle. Nell (2009:574-576) coordinates these three acts with unity, reconciliation, and justice:

[One,] to reach out with open arms and cross the many different divides between people ... [Two,] the preaching process should create spaces where people feel safe to bring the victims and victimizers into authentic relationships ... [And three,] throughout this process [of justice in theodramatic terms, the prophetic community] become witnesses to society in general of the ways in which each and everyone can play these roles [of justice] with integrity. 


\subsection{Divergences between aesthetic homiletics and prophetic preaching}

I opine that aesthetic homiletics is always explicitly and implicitly in conversation with prophetic preaching. Furthermore, the point where aesthetic homiletics diverges with prophetic preaching is at the location of moralism/ religious activism. According to Cilliers (2012a:4; 2018:8), religious activism is the postmodern development of moralism. The moralist/religious activist sermon will

[state] what God has done [in the past] and what God will do [in the future], but more importantly: what people must do to activate God's deeds now (Cilliers 2012a:5).

In his earlier works, Cilliers (see 1996; 1998; 2002a; 2002b; 2002c; 2003; 2004) thoroughly traced moralism in South African sermons and proposed an alternative homiletic theory. He also called out prophetic preaching for being religious activism. He has shown prophetic preaching to be "theological[ly] unsophisticated" (see Cilliers 2015:373) and that a prophetic sermon of Allan Boesak displays moralistic tendencies (Cilliers 2013:10-11; 2019:114-115). From these impetuses, Cilliers (2018:7, italics in original) moved to aesthetic homiletics:

But, later on, as I was searching for alternatives, I started to appreciate
aesthetics as a space which does not circle the wagons to form
enclaves, but rather a space where creativity and playfulness are no
strangers. In this regard, my German Doktorvater, Rudolf Bohren,
played a major role, teaching me that moralism and aesthetics are in
fact the exact opposite. The one clamps down, the other opens up.

With this idea that aesthetic homiletics opens up, I want to propose three focal images where aesthetic homiletics diverges with prophetic preaching, in order to bring forth newness in the world: the person of the preacher; the identity of God, and inculturation and the human spirit.

\subsubsection{The person of the preacher}

In their book Preaching fools, Campbell and Cilliers (2012:153-154) remark:

Preachers are fools. Preaching fools. At the deepest level this characterization is inescapable. For preachers proclaim the foolish, disruptive gospel of the life, death, and resurrection of Jesus ... Just as Jesus, like a trickster, crosses boundaries, breaks taboos, and speaks disruptive words, so preaching fools interrupt the social and religious - and homiletical - status quo. 
Campbell and Cilliers' perspective brings forth an image of the preacher which transcends and hybrids the preacher. Unlike the perception of the preacher as the sage who knows God's will for society (see De Wet \& Kruger 2013), the fool both in persona and actions decentres, fools, plays, breaks open new possibilities, and fragments reality. The point Campbell and Cilliers (2012:163) make is that playing the fool and fooling with the play (of life) breaks open forms of existing in the world that have become stagnant. Be they political, socio-economic, or religious. The idea of play could be brought in close relation to Nell's $(2009 ; 2017)$ concept of the preacher as a director in the theatrical play of God. Although Nell (2009:573) explicitly shies away from contemplating the person of the preacher, the ideas Campbell and Cilliers (2012:163) contribute could aid in the relationship between the theodrama of the past and the contextual theodrama:

In this way [the preaching fools] constantly remind us that what is needed is not a repetition of old paradigms, but a re-creation of them - not a cloning of what was, but a clowning for what could be.

This moves Nell's (2009:573-576; 2017:317-318) proposal away from a repetition of the past towards the possibility of newness entering the world. Furthermore, this reframing of the person of the preacher implies changing the understanding of all people. Now, the identity of persons is open for negotiation. Space and time, which underlie human character, are absorbed into the "eschatological fluidity" of the fool's gospel (Campbell \& Cilliers 2012:168).

Nell (2015) researched an exciting project named sermon of the layperson. In the project, five laypersons were selected to preach a sermon each. The criterium for selection was that "the preachers should be people with influence in society through their participation in public debate", with consideration for the plight of the vulnerable (Nell 2015:3). This project fundamentally plays with the persona of the preacher, opening space and time for new voices and perspectives to be heard. In the future, it would be interesting to see what other voices, such as people without influence in society, would bring to the table. Furthermore, in conversation with Campbell and Cilliers (2012:156-157), the space of the pulpit becomes negotiable with regard to allowing bodies previously excluded from the pulpit, due to race, class, gender, sexual orientation, or any other bodily attribute.

\subsubsection{The identity of God}

With regard to the identity of God, among a rather large variety of Godimages, I want to focus on three: the vulnerable God, God of the dance, and the absent God. 
In his contemplation on the Belhar Confession, Cilliers (2008:16) interprets the fourth article to point to God's weakness, brokenness, and vulnerability. For Cilliers (2008:16), the words

in a world full of injustice and enmity ... God is in a special way the God of the destitute, the poor and the wronged

speak of God's choice of becoming (and being) poor, marginalised, and wronged. From this perspective, contemplation on the identity of God as weak opens both the possibilities of how God is feeble and how broken people relate to God. Cilliers (2008:17; 2012b:169) proposes the following images as vulnerable God: God as a quadriplegic in a sip-puff wheelchair; a crucified donkey; a victim of a xenophobic attack, and a man with AIDS. In the vulnerability and brokenness of God, there is a certain ugliness of which Cilliers (2012b:63, italics in original) has the following to say:

Beauty, understood in theological-aesthetical sense, is not annihilated by the ugly and horrific. On the contrary, the beauty of God is often revealed exactly under such circumstances: the ugliness of the cross is the strange "beauty" of God, par excellence.

These contemplations on the vulnerability of God are truly contemplations on the weakness of human beings. For Cilliers (2012b:146), aesthetics is to locate the activity of God within the lived experience of human beings, including suffering and struggle.

When it comes to the God of the dance, Cilliers (2012b:120-121) integrates bodily movement, dancing as anticipation for harmony, and the trinitarian perichoresis:

But this glorious godly choreography - this is the wonder of grace does not remain locked up in the Trinity ... The circular dance is thus opened up, in that God as Creator, Saviour and Consummator, as it were, opens up God's arms for all of creation to come and join in the joy, to come and dance with God (Cilliers 2012b:122).

In this vision of God as dancing, Cilliers breaks the boundaries between God and human, body and soul, mundane and beautiful. The aesthetic imagination of dance blurs the lines between the sacred and the secular, between embracing the O/other and being embraced by the O/other, between the included and the excluded:

A liturgy that participates in the dance of the trinity has open arms: it embraces those who have been marginalised, stereotyped, stigmatised by society; it welcomes Aids sufferers and homosexually orientated people; it received the poor, the powerless, the vulnerable and the voiceless (Cilliers 2012b:175). 
Lastly, Cilliers contemplates the absence of God. In his thoughts on space and how the event of preaching becomes "a space for grace" both as a gift when "God enters, transcends and fluidises our spaces" and as the creation of preaching (Cilliers 2016b:31), he considers the possibility of God's absence in spaces. He examines the lived experience underscored by Samuel Beckett's Waiting for Godot and Ben Williken's Last supper, where the table is empty (Cilliers 2016b:42-45). In the interaction between these two interlocutors, Cilliers proposes the possibility that God can be absent, hidden, and elusive. Still, whereas Beckett's play is a tragedy of waiting, Williken's painting brings forth a "hermeneutics of expectation" (Cilliers 2016b:43, italics in original). The point Cilliers makes is that God's absence makes it possible for newness to enter the world. The expectation for what is to come at the empty table opens spaces for a new understanding of faith, of God, of each other, of the Holy Supper, and of life. At the same time, the empty table speaks of the presence of the absent one through the Holy Spirit (Cilliers 2016b:44). There is thus both the absence of God and the present, and the expectation of the one to come who is already here:

This table waits upon the arrival not of Godot, who never comes. This table waits upon the arrival of God, who has already come (Cilliers 2016b:44).

\subsubsection{Inculturation and the human spirit}

A third important image in aesthetic homiletics is inculturation. In his contribution to aesthetic homiletics, Vos (2014:5-7) proposes a myriad of possible usages of secular poetry, novels, art, songs, theatre, and films in the sermon to open the dialogue between the sacred and the lived experience. Inevitably, Vos (2014:7) calls for the inculturation of the event of preaching as critical reciprocity between cult and culture. Although he is restrained in his call for inculturation, underscoring the need of responsible virtue ethics for the church (Vos 2014:7), his point for the possibility for Christianity to overcome the barriers between religious and lived experience through aesthetics is of critical importance.

In a sense, all of Cilliers' aesthetic work is inherently inculturation. Especially his insights into visual art underscore the close association of preaching, aesthetics, and inculturation. In one of his contemplations of a painting of Willie Bester, Township plight, Cilliers (2016a:32-33) acutely shows how the lived experience of oppression flows through a myriad of aesthetic expressions within the struggle for justice. Over against the destructive heritage of the apartheid past in South Africa - symbolised in the painting by informal houses, a gun and bullets, and fearing faces 
- Cilliers (2016a:33) finds the "triumph of the human spirit, the (colorful) transcendence of the raw realities of the South African history of Apartheid". This idea of the human spirit which triumphs over injustice envisions newness entering the world; no, it is newness already having entered the world. Yet, this newness is the incultured expression of human struggle towards transcending the unjust.

\section{REFLECTING ON AESTHETIC HOMILETICS}

I am convinced that aesthetic homiletics showcases strong post-colonial tendencies. Although there does not seem to be a direct influence of post-colonial thought on aesthetic homiletics, there are two points where aesthetic homiletics corresponds strongly with post-colonial theory: decolonising the mind and the subject as decentred and fragmented person.

\subsection{Decolonising the mind}

Mignolo (2007) proposes that the decolonisation of the mind takes place in a double movement of exposing and affirming. Exposing means to uncover the overarching myth that privileges Western values as all-encompassing logic of salvation, while affirming refers to validating other ways of thinking, knowing, and existing in the world (see Biko 1987:70; Fanon 2004:6; Mbembe 2001:25; Ndlovu-Gatsheni 2018:3; Spivak 1988:271; Tetteh 2001:25; Vellem 2017:8; Wa Thiong'o 1986:67, 108).

In the convergence between aesthetic homiletics and prophetic preaching, aesthetic homiletics questions the overarching myth of prophetic preaching, thus deconstructing it. Furthermore, aesthetic homiletics contributes alternatives to the restricted understanding of justice as neoliberal democratic participation. Insights from thinkers throughout many disciplines, world views, and locations of culture are considered, breaking open new possibilities for living.

\subsection{The subject as decentred and fragmented person}

In his understanding of the subject, Bhabha (1994:216) proposes that a new subject emerges as decentred and fragmented at the transitional location of in-between space and temporality. This stands in direct opposition to a fixed gaze or epistemological centre that arrests the subject in time and space; either as good and righteous (the Western man), or backwards and savage (the other) (see Cornell \& Seely 2016:123; Drichel 2008:589; Wa Thiong'o 1993:34). 
As mentioned earlier, in the endeavour of aesthetic homiletics, the identity of the preacher and God is decentred and fragmented in a myriad of ways. This hybridity of identity opens new spaces, pregnant with possibilities for new relationships and interpretations of the agency of the subject. I do, however, opine that there is still a lack of contemplation on the agency of the most vulnerable in society. Stated differently, although the identity of the preacher and God has experienced thorough reflection, the character of the poor and vulnerable seems to be still fixed in time and space. Further contemplation of inculturation may be able to dislodge this rigid identity.

\section{CONCLUSION}

In this article, I have endeavoured to trace a thorough genealogy of justice and beauty in South African homiletics. In this tracing, I have reflected on prophetic preaching and aesthetic homiletics from a post-colonial perspective, with the underlying conviction that post-colonial thought deconstructs some of the blind spots of the current dialogue on justice and beauty, on the one hand, and assists in constructing new ways of perceiving, knowing, and thinking, which may aid in reconstructing thoughts on justice and beauty, on the other.

I believe that two points of this article make an essential contribution in South African homiletics. First, I have proposed that prophetic preaching's actual interlocutor is not equal to the claimed interlocutor. This has an impact on the integrity of justice as sought by prophetic preaching. Secondly, I have proposed that aesthetic homiletics has a strong postcolonial imagination. This implies that aesthetic homiletics may showcase that justice flows more readily through the openness of beauty than homiletic theory has thus far considered. 


\section{BIBLIOGRAPHY}

BHABHA, H.K.

1994. The location of culture. London: Routledge.

Bıко, S.B.

1987. I write what I like. Oxford: Heinemann.

BoEsAK, A.A.

1984. Black and reformed: Apartheid, liberation and the Calvinist tradition. Braamfontein: Skotaville Publishers.

Brueggemann, W.

1978. The prophetic imagination. Philadelphia, PA: Fortress Press.

Campbell, C.L. \& Cilliers, J.H.

2012. Preaching fools: The gospel as a rhetoric of folly. Waco, TX: Baylor University Press.

Cilliers, J.

1996. Die uitwissing van God op die kansel. Ontstellende bevindinge oor SuidAfrikaanse prediking. Cape Town: Lux Verbi.

1998. Die uitwissing van God op die kansel: Inspirerende perspektiewe op die prediking - Om God te sien en ander te laat sien. Cape Town: Lux Verbi.

2002a. Die geheim van die prediking: Om na die stem van die teks te luister. Verbum et Ecclesia 23(1):67-79. https://doi.org/10.4102/ve.v23i1.1201

2002b. Die geheim van die prediking: In-stemming met die gemeente. HTS Teologiese Studies / Theological Studies 58(1):143-156. https://doi.org/10.4102/ hts.v58i1.553

2002c. Die geheim van die prediking: Een-stemmigheid op die kansel. Nederduitse Gereformeerde Teologiese Tydskrif 43(1/2):32-38. https://doi. org/10.4102/hts.v58i1.553

2003. Die geheim van die prediking: Om mondig te word. Acta Theologica 23(1):23-35. https://doi.org/10.4314/actat.v23i1.5406

2004. The living voice of the gospel. Stellenbosch: Sun Press.

2006. God for us? An analysis and assessment of Dutch Reformed preaching during the apartheid years. Stellenbosch: Sun Press. https://doi. org/10.18820/9781920109134

2008. The clown before the powers. A South African response to Charles Campbell's comic vision on preaching. Homiletic 33(2):11-18. https://doi. org/10.15695/hmltc.v33i2.3290

2012a. Disabling God in an able world? Analysis of a South African sermon. Nederduitse Gereformeerde Teologiese Tydskrif 53(1/2):1-12. https://doi. org/10.5952/54-1-2-299 
2012b. Dancing with deity: Re-imagining the beauty of worship. Wellington: Bible Media.

2013. Prophetic preaching in South Africa: Exploring some spaces of tension. Nederduitse Gereformeerde Teologiese Tydskrif 54(1-2):1-15. https://doi. org/10.5952/54-1-2-299

2015. Where have all the prophets gone? Perspectives on political preaching. Stellenbosch Theological Journal 1(2):367-383. https://doi.org/10.17570/ stj.2015.v1n2.a17

2016a. Just preaching ... in times of transition: South African perspectives. International Journal of Homiletics 1(1):21-33.

2016b. A space for grace: Towards an aesthetics of preaching. Stellenbosch: Sun Media.

2018. Interview with Prof. Johan Cilliers. Acta Theologica 38(2):5-14. https://doi. org/10.18820/23099089/actat.v38i2.interview

2019. Timing grace: Reflections on the temporality of preaching. Stellenbosch: African Sun Media. https://doi.org/10.18820/9781928480235

Cornell, D. \& Seely, S.D.

2016. The spirit of revolution: Beyond the dead ends of man. Cambridge: Polity Press.

De Wet, F.W. \& Kruger, F.P.

2013. Blessed are those that hunger and thirst for righteousness: Sharpening the ethical dimension of prophetic preaching in a context of corruption. Verbum et Ecclesia 34(1):1-10. https://doi.org/10.4102/ve.v34i1.722

DRICHEL, S.

2008. The time of hybridity. Philosophy and Social Criticism 34(6):587-615. https://doi.org/10.1177/0191453708090330

FANON, F.

2004. The wretched of the earth. Second edition. New York: Grove Press.

HARRIS, J.H.

1995. Preaching liberation. Minneapolis, MN: Fortress Press.

Kruger, F.P. \& Pieterse, H.J.C.

2016. Reasons why government leaders, officials and church leaders have to act against corruption. In: F. Kruger \& B. de Klerk (eds.), Corruption in South Africa's liberal democratic context: Equipping Christian leaders and communities for their role in countering corruption (Durbanville: AOSIS), pp. 64-95. https://doi. org/10.4102/aosis.2016.csaldc05

Laubscher, M. \& Wessels, W.

2016. A prophetic word on studies in prophetic preaching? Re-visioning prophetic preaching's (post-)apartheid condition. In: R. Venter (ed.), Theology and the (post-)apartheid condition: Genealogies and future directions (Bloemfontein: Sun Media), pp. 171-187. 
MAIMELA, S.S.

1987. What do the churches want and expect from religious education in schools? Journal of Black Theology in South Africa 1(1):43-49.

Maluleke, T.S. \& Nadar, S.

2004. Alien fraudsters in the white academy: Agency in gendered colour. Journal of Theology for Southern Africa 120(November):5-17.

Mbembe, A.

2001. On the postcolony. Berkeley, CA: University of California Press. https:// doi.org/10.1525/9780520917538

Mignolo, W.D.

2000. The many faces of cosmo-polis: Border thinking and critical cosmopolitanism. Public Culture 12(3):721-748. https://doi. org/10.1215/08992363-12-3-721

2007. Delinking: The rhetoric of modernity, the logic of coloniality and the grammar of de-coloniality. Cultural Studies 21(2/3):449-514. https://doi. org/10.1080/09502380601162647

Mofokeng, T.A.

1987. A Black christology : A new beginning. Journal of Black Theology in South Africa 1(1):1-17.

Mosala, I.J.

1987. Black theology in South Africa and North America: Prospects for the future; building of alliances. Journal of Black Theology in South Africa 1(2):35-41.

Motlhabi, M.B.G.

1987. Black resistance to apartheid. Journal of Black Theology in South Africa 1(2):3-12.

Nolovu-Gatsheni, S.J.

2018. Epistemic freedom in Africa: Deprovincialization and decolonization. London: Routledge. https://doi.org/10.4324/9780429492204

NeLL, I.

2009. In search of meaning: Moving from the prophet's voice to prophecy in community: A South African perspective. Scriptura 102:562-578. https://doi. org/10.7833/102-0-615

2015. "Preaching from the pews": A case study in vulnerable theological leadership. Verbum et Ecclesia 36(1):1-10. https://doi.org/10.4102/ve.v36i1.1376

2017. Preaching and performance: Theo-dramatic paradoxes in a South African sermon. Stellenbosch Theological Journal 3(1):309-326. https://doi. org/10.17570/stj.2017.v3n1.a14 
Pieterse, H.J.C.

1995. Prophetic preaching in context. In: H.J.C. Pieterse (ed.), Desmond Tutu's message: A qualitative analysis (Kampen: Kok Pharos Publishing House), pp. 96-111.

2001. Preaching in a context of poverty. Pretoria: Unisa Press.

2002. Communicative rationality and hermeneutical insights for preaching in a context of poverty. Nederduitse Gereformeerde Teologiese Tydskrif 43(3/4):555-562.

2013. Prophetic preaching in the contemporary context of South Africa. In die Skriflig/ln Luce Verbi 47(1):1-6. https://doi.org/10.4102/ids.v47i1.114

Pieterse, H.J.C., Scheepers, P. \& Wester, F. 1995. Structure of thought. In: H.J.C. Pieterse (ed.), Desmond Tutu's message: A qualitative analysis (Kampen: Kok Pharos Publishing House), pp. 37-55.

RAMOSE, M.B.

1988. The two hands of God in South Africa: A review of Albert Nolan's God in South Africa. Journal of Black Theology in South Africa 2(1):18-42.

SMITH, T.

1987. Kansel en politiek. 'n Evaluering van die eietydse preekgestaltes van die politieke teologie. Cape Town: Lux Verbi.

SPIVAK, G.C.

1988. Can the subaltern speak? In: C. Nelson \& L. Grossberg (eds.), Marxism and the interpretation of culture (London: Macmillan Education), pp. 271-313. https://doi.org/10.1007/978-1-349-19059-1_20

TetTeh, I.N.O.

2001. The inspired African mystical gospel. Accra: Etherean Mission Publishing.

Tubbs Tisdale, L. \& De Wet, F.W.

2014. Contemporary prophetic preaching theory in the United States of America and South Africa: A comparative study through the lens of shared Reformation roots. HTS Teologiese Studies / Theological Studies 70(2):1-9. https://doi. org/10.4102/hts.v70i2.1337

Vellem, V.

2012. Interlocution and Black Theology of Liberation in the $21^{\text {st }}$ century: A reflection. Studia Historiae Ecclesiasticae 38:1-9.

2017. Un-thinking the West: The spirit of doing Black Theology of Liberation in decolonial times. HTS Teologiese Studies / Theological Studies 73(3):1-9. https://doi.org/10.4102/hts.v73i3.4737

2018. Interview with Vuyani S. Vellem. Acta Theologica 38(1):1-14. https://doi. org/10.18820/23099089/actat.v38i1.1 
VORSTER, J.M.

1992. Die eise aan die gereformeerde prediking in die teenswoordige kultuur van verandering. In die Skriflig / In Luce Verbi 26(4):451-463. https://doi.org/10.4102/ ids.v26i4.1429

Vos, C.J.A.

2014. 'n Literêr-estetiese benadering van homiletiek in ' $n$ veranderende kultuur. In die Skriflig / In Luce Verbi 48(2):1-9. https://doi.org/10.4102/ids.v48i2.1710

WA THIONG'O, N.

1986. Decolonising the mind: The politics of language in African literature. Nairobi: East African Educational Publishers.

1993. Moving the centre: The struggle for cultural freedoms. Nairobi: East African Educational Publishers.

Wepener, C.J. \& Pieterse, H.J.C.

2018. Angry preaching: A grounded theory analysis from South Africa. International Journal of Public Theology 12(1):401-415. https://doi. org/10.1163/15697320-12341549

Wessels, W.

2017. Contemplating Allan Boesak's fascination with preaching "truth to power". Acta Theologica 37(2):188-206. https://doi.org/10.18820/23099089/ actat.v37i2.11

2020. Postcolonial homiletics? A practical theological engagement with postcolonial thought. Unpublished PhD thesis. Pretoria: University of Pretoria.

West, G.O.

2016. The stolen Bible: From tool of imperialism to African icon. Boston, MA:

Brill. https://doi.org/10.1163/9789004322783

Keywords

Prophetic preaching

Aesthetic homiletics

Post-colonial theory
Trefwoorde

Profetiese prediking

Estetiese homiletiek

Post-koloniale teorie 